\title{
Methodological Aspects of Strategic Controlling of Digital Transformation of Transport and Logistics System
}

\author{
Elena Balashova \\ Department of Innovation Economics \\ State Marine Technical University \\ St. Petersburg, Russia \\ elenabalashova@mail.ru
}

\author{
Elena Palkina \\ Department of Innovation Economics \\ State Marine Technical University \\ St. Petersburg, Russia \\ elena_palkina@hotmail.com
}

\author{
Elena Schislyaeva \\ Department of International Economic \\ Relations \\ State Marine Technical University St. \\ Petersburg, Russia \\ schislyaeva@smtu.ru
}

\begin{abstract}
The present technological mode featuring the use of end-to-end digital platforms and technologies has caused transition of the transport branch to the qualitatively new development level - intellectualisation of transportation organization. An important condition for provision of competitiveness of the national transport and logistical system in the world market of transport services is intensification of innovative activity of economic subjects in accordance with the main vector of its development - increase of the speed of delivery of cargoes and transportation of passengers. To raise efficiency and productivity of the process of digital transformation on transport, it is proposed to use the tool of strategic controlling. The article describes the main issues of methodology of strategic controlling in part of building its basic element - the system of indices of innovative activity closely tied with the purposes of its implementation corresponding to the specificity of transport and logistical activity and expectations of its key stakeholders. The article describes the main feasibilities and threats of presently used and prospective digital solutions in transport which are recommended to be considered during upgrading of transport and logistical system. To solve the tasks of the research work, indicative method of planning was used, and also methods of expert estimates, generalisation, grouping, probability and impact matrix. The proposed system of indices of innovative development of transport and logistical system is designed to provide successful and efficient achievement of its strategic goals in the area of digital transformation, monitoring of innovative activity of economic subjects on micro-, meso- and macro levels of management. Revelation of the present day challenges of digital development of transport generates the basis for preparation of activities aimed at increase of efficiency of transport and logistical system functioning, achievement of the maximum positive synergetic effect by all the participants of transport process.
\end{abstract}

Keywords-indices of digital transformation, transport and logistical system, innovative development of transport, intellectual transportation systems, digital technologies, feasibilities, challenges, threats

\section{INTRODUCTION}

In the present conditions of the sixth technological mode formation, whose core is made by preferably digital, information and communication technologies, capability of economic subjects to quickly adapt themselves to the occurring dynamic deep changes and also ability to influence them purposely is the most important feature of management efficiency, which provides for their competitiveness and development in long-term prospective. A separate significant direction is digital development of transport and logistical system, one of the key links of socio-economic relations.

Today, consumers of transport services have already got used to apply e-tickets, on-line payment services, navigation systems, preparation of e-requests, tracking transport moving and the process of delivery in the real time mode. In the nearest future, unmanned transport, intellectual transport systems (ITS) which will be able to independently control the transportation process will be widely spread. In the Russian Federation, special attention is paid to innovative development of transport. Information and communication technologies, unmanned technologies of transport control are being integrated, specialized geo-detection equipment for location finding is used, signals received from rolling stock, information from numerous IP-video cameras are registered and analyzed, "smart stations" are being built, speed of cargo delivery and passenger transportation is increased [1, 2]. In order to provide achievement of the maximum positive effect from digital transformation of transport complex official project "Digital Transport and Logistics", which is being developed within the framework of the state program on transport development [2] is aimed to solve the following tasks relating to these processes, namely: "to generate single digital transport space in Russia, make passenger and cargo transportation safer, more comfortable, accessible for people and business, to reduce expenses, broaden export and transit capabilities".

Scientific research in the area of methodology of selforganization of transport processes and ITS architecture, simulation modeling of dynamic transport processes, development of computer and electronic transport technologies [3-5] is conducted on the basis of laboratory of intellectual transport systems of the Institute of Problems of Transport named after N.S. Solomenko. Besides, other researchers put a greater emphasis on the problems of ITS development in Russia [6-8]. At that, it is important to take into account the leading foreign experience within that area to provide for complete implementation of ITS functionalities at execution of planned values of indices of investment efficiency. It is worth mentioning that in the world practice intellectual transport systems are regarded from the position 
of implementation of the concept of steady development as system changes aimed at the following: rendering various innovative services for various kinds of transport; achievement of reliable mobility through raising efficiency, safety and providing eco-friendly transport [9]. Foreign specialists point out the following problems which some countries had to face while integrating ITS: fragmentation of standards on operational compatibility, different rates of ITS projects implementation in various regions, the issues of responsibilities distribution, lack of understanding of changes in the society, insufficient level of training regarding ITS issues or its absence, lack of infrastructure, insufficient protection of personal data, unresolved issue of providing radio frequencies etc. [10].

Strategically controlling is an effective tool of achievement of strategic goals in the area of digital transformation of transport and logistical system among which one should mention the following: raising productivity, efficiency, quality of control of transportation process with the use of innovations, provision of technological leadership, necessary rational financing of innovative activity. The basic element of strategic controlling is the system of indices of innovative activity which are designed to formalize strategic goals in the area of transport and logistics, evaluation of the degree and efficiency of their achievement, revelation of causes of deviations of factual results from the target values of indicators and serve as a basis for development of measures on perfection of innovative processes in transport, raising productivity and efficiency of transportation activity. At that, the methodology of forming the system of indices of digital transformation of transport and logistical system, being an actual scientific and practical task, has presently not found the due solution in scientific literature [11-13]. This defines the purpose of the present research work.

\section{MATERIALS AND METHODS}

The concept of stakeholders, and also system approach to management have made the scientific basis of the research. When defining the technical and economic parameters of digital transport and logistical system, indicative method of planning, methods of expert estimates, generalization and grouping were used to synthesize the results of identification and analysis of today's challenges to digitalization in the area of development of transport and logistics, i.e. probability and impact matrix.

Legislative and normative documents, statistical data, materials of scientific and practical conferences, specialized literature reflecting actual issues of development of methodology of strategic controlling and today's trends of economy digitalization have been used in the work.

\section{RESULTS}

The vector of innovative development of transport is determined by such an important qualitative characteristic of transport process as the speed of delivery of cargoes and transportation of passengers. Speed increase contributes to growth of labor and transport facilities productivity, infrastructure, increase of efficiency of functioning and competitiveness of transport and logistical system. A distinctive feature of innovative scenario of the Russian Federation Transport strategy for the period up to 2030 is acceleration of cargoes delivery and passengers transportation based on construction of high-speed highways and construction of high-tech objects of transport infrastructure at provision of eco-friendly, safe and accessible transport services [14]. A feature of innovative activity of transport and logistical companies is prevailing of technological innovations relating to integration of the new and substantially improved method of organization of delivery of cargoes and transportation of passengers.

Significant changes in the know-how of transportation process, transport facilities, transport infrastructure objects, software relate to them. The degree of innovation of a new product/technology (intensity of innovation changes) in transport can be evaluated from the position of influence on the speed of transportation: innovations in transport which provide the speed of motion more than $400 \mathrm{~km} / \mathrm{h}$ are proposed to be considered innovative, in the opposite case, they are considered as improving changes [7].

The carried out research allowed to point out the most significant principles of forming the systems of indices of digital transformation of transport and logistical system, among which the following is worth noting: compliance of general strategy of transport development, reflection of strategic goals in the area of innovative activity of economic subjects, capacitance, compactness, adequacy to branch specificity, account of stakeholders interests, contents of information on economic, social, technological trends.

Review of modern literature allowed to distinguish a representative set of indices featuring efficiency, quality, productivity of operation of transport and logistical system $[10,14,15]$.

When designing the indicative frame of the intellectual transport and logistical system, we propose to follow the expectations of the key concerned sides: the state, business society, social organizations and population. Based on interests of the above concerned sides in the area of development of transport and logistics, we defined the total of projections of the system of indices of digital transformation of the transport and logistical system, and we offered a set of indicators on each goal to carry out the functions of strategic controlling (Table 1).

TABLE I. INDICATORS OF STRATEGIC CONTROLLING OF DIGITAL TRANSFORMATION OF TRANSPORT AND LOGISTICAL SYSTEM FROM THE POSITION OF EXPECTATIONS OF THE KEY STAKEHOLDERS

\begin{tabular}{|c|c|c|}
\hline Stakeholders & $\begin{array}{c}\text { Expectations of } \\
\text { stakeholders }\end{array}$ & Indicators \\
\hline 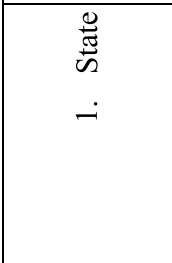 & $\begin{array}{l}\text { Generation and } \\
\text { implementation of } \\
\text { industrial, } \\
\text { innovative, transport } \\
\text { and transit, } \\
\text { investment and } \\
\text { tourist potentials }\end{array}$ & $\begin{array}{l}\text { GDP growth rate; Transport } \\
\text { share in GDP generation; } \\
\text { Off-the-transport effect; } \\
\text { Absence of transport limitations } \\
\text { for development of tourism, } \\
\text { industry, innovative } \\
\text { infrastructure; } \\
\text { Labour productivity }\end{array}$ \\
\hline
\end{tabular}




\begin{tabular}{|c|c|c|}
\hline & $\begin{array}{l}\text { Development of } \\
\text { transport } \\
\text { infrastructure }\end{array}$ & $\begin{array}{l}\text { Cargo turnover; Passenger } \\
\text { turnover; Length of operational } \\
\text { routes; Availability of rolling } \\
\text { equipment; Percentage of wear } \\
\text { of the main production funds on } \\
\text { transport; The quantity of } \\
\text { "narrow places" on the sections } \\
\text { of transport infrastructure; } \\
\text { Throughput capacity of } \\
\text { infrastructure; } \\
\text { Density of transport network; } \\
\text { Share of transport network fitted } \\
\text { with terminals of satellite } \\
\text { navigation system }\end{array}$ \\
\hline & $\begin{array}{l}\text { Provision of } \\
\text { transportation safety }\end{array}$ & $\begin{array}{l}\text { Number of road traffic accidents; } \\
\text { The number of objects increasing } \\
\text { traffic safety; Transport risk } \\
\text { level }\end{array}$ \\
\hline \multirow[t]{2}{*}{ Stakeholders } & $\begin{array}{c}\text { Expectations of } \\
\text { stakeholders }\end{array}$ & Indicators \\
\hline & $\begin{array}{l}\text { Increase of return of } \\
\text { duties into budget }\end{array}$ & $\begin{array}{l}\text { The volume of return of duties } \\
\text { into budget, including the ones } \\
\text { from transport organisations }\end{array}$ \\
\hline \multirow{4}{*}{ 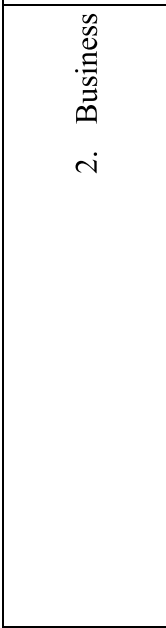 } & $\begin{array}{l}\text { Provision of } \\
\text { transportation safety }\end{array}$ & $\begin{array}{l}\text { The level of safety of cargoes; } \\
\text { Transport risk level }\end{array}$ \\
\hline & $\begin{array}{l}\text { Decrease of transport } \\
\text { expenses }\end{array}$ & $\begin{array}{l}\text { Share of transport component in } \\
\text { the product price }\end{array}$ \\
\hline & $\begin{array}{l}\text { Increase of the } \\
\text { quality of transport } \\
\text { services }\end{array}$ & $\begin{array}{l}\text { Index of the quality of transport } \\
\text { services }\end{array}$ \\
\hline & $\begin{array}{l}\text { Reducing the time of } \\
\text { cargo delivery }\end{array}$ & $\begin{array}{l}\text { The time of "house to house" } \\
\text { cargo delivery; Specific weight } \\
\text { of non-production out-of-service } \\
\text { time in the total time budget of } \\
\text { transport facility; The average } \\
\text { commercial speed of goods } \\
\text { flow; Effect from acceleration of } \\
\text { cargo delivery (release of } \\
\text { current assets from } \\
\text { cargoholders) }\end{array}$ \\
\hline 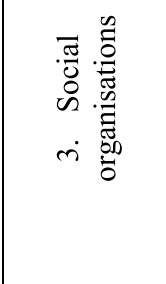 & $\begin{array}{l}\text { Minimisation of } \\
\text { negative impact on } \\
\text { environment }\end{array}$ & $\begin{array}{l}\text { The average specific } \\
\text { fuel/electrical energy rate; the } \\
\text { quantity of hazardous emissions } \\
\text { into the atmosphere; Decrease of } \\
\text { noise impact on the environment; } \\
\text { Share of recoverable waste; } \\
\text { Share of alternative kinds of fuel } \\
\text { in the total fuel consumption }\end{array}$ \\
\hline \multirow{4}{*}{ 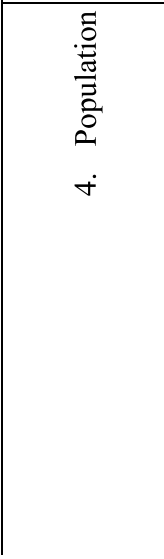 } & $\begin{array}{l}\text { Provision of } \\
\text { transportation safety }\end{array}$ & Transport risk level \\
\hline & Mobility increase & $\begin{array}{l}\text { Coefficient of transport mobility } \\
\text { of population; Share of } \\
\text { inhabitants having access to } \\
\text { regular transport services }\end{array}$ \\
\hline & $\begin{array}{l}\text { Decrease of transport } \\
\text { expenses }\end{array}$ & $\begin{array}{l}\text { Share of expenses for passage in } \\
\text { the budget of household; } \\
\text { Average cost of passage }\end{array}$ \\
\hline & $\begin{array}{l}\text { Increase of the } \\
\text { quality of transport } \\
\text { services }\end{array}$ & $\begin{array}{l}\text { Number of fuel stations; The } \\
\text { number of objects of road } \\
\text { service; Absence of transport } \\
\text { limitations for access to } \\
\text { destination; Rhythm; Transport } \\
\text { services quality index }\end{array}$ \\
\hline
\end{tabular}

\begin{tabular}{|l|l|l|}
\hline $\begin{array}{l}\text { Decrease of time of } \\
\text { passengers } \\
\text { transportation }\end{array}$ & $\begin{array}{l}\text { Speed of motion of passenger } \\
\text { transport; } \\
\text { Duration of travel; } \\
\text { The value of social effect } \\
\text { (evaluation of saving time } \\
\text { during travel) }\end{array}$ \\
\cline { 2 - 3 } $\begin{array}{l}\text { Reducing time of } \\
\text { waiting for transport }\end{array}$ & $\begin{array}{l}\text { The time of expectation of } \\
\text { delivery of transport, including } \\
\text { the end route points and } \\
\text { interchange stations }\end{array}$ \\
\hline
\end{tabular}

Presented indicators form the subsystem of control of digital transformation of transport and logistical system. On each index certificate shall be prepared within the framework of automated control system in which formula, calculation periodicity of index, measurement unit, information sources to be defined that are necessary for its evaluation and also the list of positions for which this index is applied for estimate of activity and motivation. Besides, for each of the enumerated indicators one should define the target value for the definite period of planning that will allow to provide efficiency monitoring and productivity of achievement of strategic goals, and if necessary, to operatively introduce the correcting actions.

At that, in strategic management of transport and logistics development one should take into account the challenges of digital transformation which might significantly influence the results of innovation of transport and logistical processes and their possible consequences.

Challenge 1 (feasibility). Introduction of the system of biometric identification of personality with the use of method of recognition of a face will allow to raise the safety in transport and cut short the time for monitoring procedure; recognition of people in public spaces that is especially actual for such transport hubs as airports where passenger's person monitoring is made at the entrance to the airport, at customs passport and visa check points, boarding on a plane, and also for metro stations and railway stations. Development of this direction of biometry allows to highly accurately recognizing a man thanks to usage of face 3D scan. Thus, for example, at Hong Kong airport, thanks to operation of smart terminals, check-in for a flight takes a few minutes only.

Challenge 2 (feasibility). Development of computers, software and artificial intellect. Usage of supercomputer equipment allows organizations involved in transportation process to integrate into a single information and communication system. Wide application of tools of mathematical modeling allows optimizing logistical chains and routes from the point of view of reducing time of cargo delivery/passenger transportation and expenses for transportation for clients of transport organizations. Today, there is also a possibility to track parameters of delivery in online mode, estimate time of expectation of arrival of transport that allows to more efficiently plan time. In its turn, digital technologies allow transport and logistical companies to choose optimal methods of delivery, plan routes depending on road loading, track location and status of cargoes/passengers, optimize the operation of personnel.

As to leading information systems which serve as a digital frame of the up-to-date transport complex of the Russian Federation, from 2013, the Uniform State Information System of Transport Safety Provision is integrated, which was 
recognized by the society of experts one of the best in the world. It allows to monitor passenger transportation with detailing up to specific transport or passenger. ERAGLONASS state automated information system has been created and function, Platon system has been integrated and is successfully used. These systems allow to collect and store big data, on which basis it is possible to propose new services to clients (for example, introduction of additional information services for ERA-GLONASS system: "Help on the Road", "Evacuation", "Emergency Commissar", "Security Services", "Juridical Assistance") that creates positive effects for all the participants of transport process. On their basis, a passenger might get a better service which is more addressing, closer to his demands. The business community may get optimization of processes and saving of their expenses correspondingly. The state which provides the process with infrastructure, on the account of more its more optimal usage can get a big through capacity [2]. Also, processing, study and analysis of big data arrays are used as a basis for increase of the quality of management solutions and transition to digital control. Development of technologies of operation with big data volumes and fast growth of computer capabilities allow to create algorithms of situation evaluation operating in real time mode. Being a driver for development of navigation technologies and intellectual transport system, Glonass JSC generates the regional network of automated system of object monitoring for customers. The system functionality allows to carry out monitoring over movement of transport with a possibility to read the running, register violation of speed regimes, check fuel consumption, follow the modes of cargo transportation etc. [16].

The potential of artificial intelligence today is used, for example, by airport enterprises during determination of pricing, forecast passenger flows, loading of terminals, and also in the area of predictive repairs of planes, accumulating information on what routes the planes fly, what the weather conditions in this or that area are, what the quality of take-off runway is in this airport, what the infrastructure is [2].

In addition, the field of application of unmanned aerial aircraft systems (UAS) is constantly expanding. Their park is growing rapidly. Thus, in accordance with experts' estimates, by 2020 , the number of permissions for usage of air space will grow almost 16-fold if compared with 2015. UAS are preferably used during production of video shooting, advertisement, monitoring in various infrastructure areas, and also in agriculture. In the nearest future, they expect rapid growth of UAS usage in the area of logistics [2]. The Rosavtodor company has been implementing Karavan project for the second year successively, which includes preparation of road infrastructure for motion of unmanned automobiles. One of the examples is implementation within the framework of Karavan project of pilot travel of unmanned automobile along the Federal Route "Kazan - Naberezhnye Chelny" [17].

In the Russian Federation, digital platform of transport system to be generated for creating of trusted space for interaction of all the participants of the branch, which will unite all the above services and data arrays and become an ecosystem for all the participants of transport and logistical processes. On the basis of Russian software "a single window" of the state and business society will be created during execution of all transportations. This platform will establish the common standards, rules and information exchange schedule, including the juridical significant data on transport infrastructure and transports [2].

Challenge 3 (feasibility). Presently, thanks to smart phones, which have replaced mobile telephones, and which may specify the current location of the owner, generalize information on visited web-sites, contacts and other information, there has occurred a possibility to forecast demand, conduct more efficient personified marketing. Besides, usage of up-to-date communication means, development of specialized applications when organizing transport and logistical services may be of use for handicapped people. Mini-I-pads are used today in aviation transport as well. Thus, for instance, air stewards of the Aeroflot company are using the Russian development Crew Tablet, using which the senior air steward "sees" all the passengers, their transfers, the number of passenger's children in the plane, what food has been ordered and what questions they have. At the end of the flight, a stewardess signs in a special dialogue window, and the flight is over, closed. In the nearest future, it will be possible to accept orders for food in the plane, sell SkyShop goods on these tablets [2].

Challenge 4 (feasibility). Organization of personnel training for digital economy with active participation of universities with employers will allow to solve the problem of shortage of qualified personnel in high-tech, including the ITsphere, that will increase efficiency of scientific researches associated with creation of prospective innovation developments and their wide integration in practice. This requires creation of new educational program which are future-profession-oriented.

Challenge 5 (threat). Financial and economic structure changes cardinally. In the new conditions of capital turnover rate increase, one can see essential modification of interpretation of such notion as, for example, "labor productivity", approaches to evaluation of economic results of companies operation change. Increase of capital turnover rate generates higher requirements to support of transport organization sales profitability. Assets profitability is the generalized factor of efficiency of use of transport organization investment potential. In its turn, profitability of sales is defined by the value of cargo and passenger turnover, level of rates, the volume of expensed of transport organization on the main activity, and the productivity of assets depends on the productivity of rolling stock, cargo capacity of transport facilities, duration of operational time, speed of transportation and cost of transports. It is worth mentioning that transport and logistical business is not distinguished by high indexes of sales profitability. In this connection, to keep attraction as an investment for investors, both existing and potential, transport and logistical companies have to immediately start implementation of a set of measures aimed at acceleration of capital turnover. This means firstly acceleration of business processes of transport and logistical activity and reduction of time of delivery of cargoes/ transportation of passengers by means of integration of various mobile services, analysis of logistics "from house to house". In Russia, at the authority federal level, goals and tasks are defined in the area of organization of multi-modal cargo transportations with the use of digital technologies, namely: creation of platform solutions for carrying out seamless transportations, fast and high-quality processing of cargoes, including trans-border movement, their supervision 
at all the stages of transportation with the use of tracking systems and electronic consignment notes, and in the area of multi-model passenger transportations that supposes elimination of frontiers between various kinds of transport and providing possibility for a passenger to get "from house to house" by optimal route with guaranteed level of comfort and safety. The task of digital services in this direction is in harmonizing schedules of various kinds of transport, account of start and completion of the transportation stage, maintenance of baggage when a passenger uses a travel card, the possibility of instant choice for a passenger of optimal routes using all kinds of transport in any combination, on the basis of single digital platform of multi-modal passenger transportations [2]. To save time by reducing operations of business processes is possible using the Internet of things. Thus, thanks to the use of this technology, the Russian company PJSC Aeroflot managed to substantially increase the coefficient of efficiency, as all the planes, including Sukhoi Superjet, inform about their technical state in the air via satellite, and ground services, while waiting for their arrival, prepare the necessary spares, place in hangar to quickly maintain the plane and start its operation again [2].

Challenge 6 (threat). Industrial integration of 3-D printout may principally influence the market of transport and logistical services. Achievements in 3-D printout may cardinally change the transport logistics, routes, to cut short the need in transport and logistical services, if production location will be in the place of consumption with placing in service of these printers by economic subjects which eliminate the necessity of trans-border dispatch of end products - all that is necessary to printout on-site, it is enough to download the required file for 3D-printer.

Challenge 7 (threat). Substantial release of personnel in transport. Fast growth of labor productivity is observed in the new branches relating to data processing, creation of content and software products that as a whole lead to fast loss of significance of man as a productive unit. Today, for example, one programmer can manage a complicated and powerful data portal, replacing dozens of other employees. The same situation is at the production sites - installation of robotized automated production lines, creation of completely automated production decreases the demand of employer in personnel that substantially saves expenditures for social payments. By a number of estimates, within the nearest 20 years up to $50 \%$ of professions existing today will lose importance. All this in total leads to serious problems in employment, including transport branch.

Challenge 8 (threat). Development of content, processing of technologies of virtual and added reality creates conditions of further atomization of society - more and more time man will spend not in the real, but in a virtual world. If applied to transport and logistics, this might lead to decrease in demand for passenger transportation, as people can travel and know the world in virtual space, integration of Internet technologies (Skype, WhatsApp etc.) allows relatives, friends and business partners to communicate, and also conduct labor activity remotely that decreases population mobility and demand for transport services.

Evaluation of the level of influence of the above challenges of digital development of transport and logistical system causing positive and negative risks in achievement of set strategic goals is given as a probability and impact matrix in Figure 1.

\begin{tabular}{|c|c|c|c|c|c|c|c|c|c|c|}
\hline Probabilit & \multicolumn{5}{|c|}{ Threats } & \multicolumn{5}{|c|}{ Advantageous feasibilities } \\
\hline 0.90 & 0.05 & 0.09 & 0.18 & 0.36 & 0.72 & $\begin{array}{c}\text { F2 } \\
0.72\end{array}$ & $\begin{array}{c}\text { F4 } \\
0.36\end{array}$ & 0.18 & 0.09 & 0.05 \\
\hline 0.70 & 0.04 & \begin{tabular}{|c|} 
T4 \\
0.07
\end{tabular} & 0.14 & $\begin{array}{c}\text { T1 } \\
0.28\end{array}$ & 0.56 & \begin{tabular}{|c|} 
F1 \\
0.56
\end{tabular} & 0.28 & 0.14 & 0.07 & 0.04 \\
\hline 0.50 & 0.03 & 0.05 & \begin{tabular}{|c|} 
T3 \\
0.10
\end{tabular} & $\begin{array}{c}\text { T2 } \\
0.20\end{array}$ & 0.40 & \begin{tabular}{|c|}
$\mathbf{F 3}$ \\
0.40
\end{tabular} & 0.20 & 0.10 & 0.05 & 0.03 \\
\hline 0.30 & 0.02 & 0.03 & 0.06 & 0.12 & 0.24 & 0.24 & 0.12 & 0.06 & 0.03 & 0.02 \\
\hline 0.10 & 0.01 & 0.01 & 0.02 & 0.04 & 0.08 & 0.08 & 0.04 & 0.02 & 0.01 & 0.01 \\
\hline & $\hat{2} \frac{3}{0}$ & 응 & 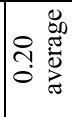 & 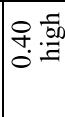 & 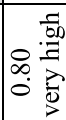 & 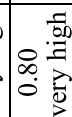 & 욤. & 焉 & $\stackrel{ }{\circ} \underset{0}{0}$ & $\therefore \frac{3}{0}$ \\
\hline
\end{tabular}

Fig. 1. The matrix of probability and impact of today's challenges of digitalisation for development of transport and logistical system

Explanations to Fig. 1 Feasibilities:

$\mathrm{F} 1$ - introduction of the system of biometric identification of a person with a use of the method of face recognition,

F2 - improvement of computers, mathematical modeling systems, big data,

F3 - usage of smart phones and mobile applications, F4

- preparation of personnel for digital economy, Threats:

$\mathrm{T} 1$ - acceleration of capital turnover, T2

- significant release of personnel,

$\mathrm{T} 3$ - widening of application of 3D printout,

T4 - development of content of virtual and added reality.

The area of dark grey color in Fig. 1 (the highest numeric values) signifies the high level of risk, the lighter area (the lowest numeric values) signifies the low level of risk, and the lightest area (average numeric values) signifies the average level of risk.

\section{DISCUSSION}

The results of research received add to existing methodological provisions of strategic controlling, develop methodological basis of the branch managerial science. The proposed system of indices of innovative development of transport and logistical system is designed to provide successful and efficient achievement of its strategic goals and generates the scientific and methodological basis for monitoring of innovative activity of economic subjects on micro-, meso- and macro levels of management.

Determination of target values of the indices presented are required to be established on the basis of results of independent technological audit. At that, it is reasonable to be oriented at the best world practice - similar indices of the leading world competitors by results of benchmarking conducted with establishment of definite transitional period for achieving them with the aim to increase, provide the required competitiveness level of the Russian transport and logistical companies and the national transport system. As a whole, intellectual management systems shall be designed to contribute to improvement of the quality of transport services, mobility of population, safety of transportation, decrease of 
transport expenditures, reducing time of delivery, waiting for transport, minimization of its negative impact on the environment, strengthening of market positions of enterprises, regional economies of the country by means of generating and implementing competitive advantages on the innovative basis. Revelation of today's challenges of digital development of transport and logistical system generates the basis for development of measures aimed at increase of efficiency and productivity of its functioning, provision of achievement of the maximum positive effect by all the participants of transport and logistical activity.

\section{CONCLUSIONS}

Planning of functioning of intellectual transport and logistical systems based on the proposed above indices will allow to consider growth of tourist, industrial, scientific and technical potentials of territorial entity, develop forecast of business activity, stimulate economic and social growth by means of impact on expectations of the parties interested, while maximally using the degree of their support and feasibility to have impact of the main business processes that, as a result, will contribute to achieve the strategic goals set. While generating the digital frame of the national transport and logistical system, it is necessary to take into account its forthcoming integration into the global infrastructure. This will allow to create new opportunities for the population, business and state, strengthen the role of the country in the world transport and logistical and information and communication systems.

Further development of the subject may be associated with constructing mathematical models allowing to provide for the balance of interests of various groups of stakeholders when taking managerial decisions in the area of transport and logistics development, and also with integration of indices of digital transformation of transport and logistical system into a summary forecast model of socio-economic development of the country.

\section{REFERENCES}

[1] Program "Digital Economy of the Russian Federation," approved by the Order of the Government of the Russian Federation on July 28, 2017, vol. 1632-r, 2017.

[2] Verbatim of the Meeting "About the Digital Transformation of the Transport Complex," under the leadership of the Prime Minister of the Russian Federation D. A. Medvedev 23.11.2018 [Online], available at: http://government.ru/news/34821/ (Accessed: 12.04.2019)

[3] Ya. A. Seliverstov and S. A. Seliverstov, "Model of Intellectualization of Transport and Logistics System," Development of Infrastructure and Logistics Technologies in Transport Systems: Proceedings of the International Scientific and Practical Conference, St. Petersburg, 2016, pp. 326-338.

[4] S. A. Seliverstov, Ya. A. Seliverstov, O. Yu. Lukomskaya, and A. V. Kurakov, "Overview Stages of Transport Systems Intellectualization," [Transport of Russia: Problems and Prospects - 2016: Proceedings of the International Scientific and Practical Conference, St. Petersburg, Solomenko Institute of Transport Problems of the Russian Academy of Sciences, 2016, pp. 193-201].

[5] Ya. A. Seliverstov, G. Yu. Gergel', S. A. Seliverstov, and K. V. Nikitin, "Development of Intelligent Transport Systems Based on Mobile Technologies and Analysis of Social Activity of Urban Population," Scientific and technical journal of Saint Petersburg state polytechnic University. Informatics and telecommunications. Upravlenie, vol. 11, no. 1, 2018, pp. 47-64.

[6] S. V. Zhankaziev, "Development of Projects for Intelligent Transport Systems," Moscow: MADI, 2016, p. 104.
[7] L. F. Kazanskaya and E. S. Palkina, "Innovative Imperatives for Competitiveness of National Transport Systems in Conditions of Globalization," [Globalization and Its Socio-Economic

Consequences:16th International Scientific Conference, University of Zilina, Rajecke Teplice, Slovak Republic, 5th - 6th October 2016, Part II, WOS:000393253800104., 2016, pp. 839-846].

[8] E. Balashova, I. Krasovskaya, E. Schislyaeva, and F. Shamrai, "Calculation and analytical instrumentarium for estimating the economic efficiency of the digital technologies development process," [IOP Conference Series: Materials Science and Engineering, DOI:10.1088/1757-899X/497/1/012107, 2019].

[9] UNECE Transport Division, SINA, "Intelligent Transport Systems (ITS) for sustainable mobility," [Online], available at: https://www.unece.org/fileadmin/DAM/trans/publications/Intelligent Transport_Systems_for_Sustainable_Mobility.PDF_Accessed: 15.05.2019).

[10] Intelligent Transport Systems - Concept Note by the Inland Transport Committee of the Europe Economic Commission at the United Nations Organization [Online], available at: https://www.ipu.ru/sites/default/files/users/939/ECE\%20TRANS\%20 2016\%2010.pdf (Accessed: 30.04.2019).

[11] V. B. Ivashkevich, "Strategic Controlling," Moscow: NITs Infra-M, 2013, p. 216.

[12] C. S. Chapman, "Controlling Strategy: Management, Accounting and Performance Measurement," Oxford University Press, 2005, p. 204.

[13] R. Kaplan and D. Norton, "The Balanced Scorecard: Translating Strategy into Action," Moscow: Olimp-Business, 2006, p. 304.

[14] Transport Strategy of the Russian Federation for the period up to 2030: approved by the Order of the Government of the Russian Federation on November 22, 2008, vol. 1734-r [Online], available at: http: // https://www.mintrans.ru/documents/3/1009 (Accessed: 18.04.2019).

[15] Transport in Russia - 2018, Statistical Book, Moscow: Rosstat, 2018, p. 101.

[16] Official website of the Association for the Development of Digital Transport Technologies "Digital Era of Transport" [Online], available at: http://digitalagetransport.ru (Accessed: 25.05.2019). 